\title{
Antiviral activity of novel oseltamivir derivatives against some influenza virus strains
}

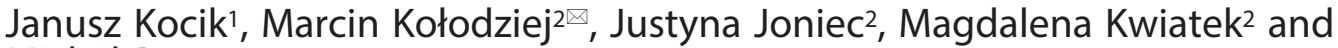 \\ Michał Bartoszcze 2 \\ ${ }^{1}$ Military Institute of Hygiene and Epidemiology, Warsaw, Poland; ${ }^{2}$ Biological Threats Identification and Countermeasure Center of MIHE, Puławy, \\ Poland
}

\begin{abstract}
The aim of this study was to investigate the in vitro cytotoxicity of oseltamivir derivatives and determine their activity against $\mathrm{A} / \mathrm{H} 1 \mathrm{~N} 1 / \mathrm{PR} / 8 / 34$ and $\mathrm{A} / \mathrm{H} 3 \mathrm{~N} 2 / \mathrm{Hong}-$ Kong/8/68 - strains of influenza virus. Antiviral activity of these compounds was determined by using two methods. MTT staining was used to assess the viability of MDCK cells infected with influenza viruses and treated with various concentrations of drugs. In parallel, the effect of drugs on viral replication was assessed using the hemagglutination test. The most toxic compounds were: OS-64, OS-35, OS-29, OS-27 and OS-25, whereas OS-11, OS-20 and OS-23 were the least toxic ones. Statistically significant antiviral effect at a higher virus dose was shown by compounds: OS-11, OS-20, OS-27, OS-35, and OS-64. H3N2 virus was sensitive to 10-times lower concentrations of OS-11 and OS-35 than H1N1. At a lower infection dose, the antiviral activity was observed for OS-11, OS 27, OS-35 and OS-20. OS-64 turned out to be effective only at a high concentration. OS-23 showed no antiviral effect.
\end{abstract}

Key words: influenza virus, neuraminidase inhibitors, oseltamivir, antiviral activity, cytotoxicity

Received: 26 August, 2014; revised: 27 August, 2014; accepted: 27 August, 2014; available on-line: 12 September, 2014

\section{INTRODUCTION}

According to WHO, every year $5-10 \%$ of adults and $20-30 \%$ of children fall ill with flu, $3-5$ million patients require hospitalization, and 250000-500000 die (http:// www.who.int/mediacentre/factsheets/fs211/en/). The large variability of the virus makes the disease difficult to control and eradicate. Frequent point mutations (antigenic drift) and the exchanges of viral RNA segments between strains (antigenic shift) favour the emergence of new variants, potentially threatening to people. For example, the avian influenza H5N1 virus, which has been detected in humans since 1997, displayed an extremely high virulence (http://www.who.int/mediacentre/ factsheets/avian_influenza/en/). Then, in 2009, a new pandemic variant H1N1 managed to spread across almost the entire globe in just a few weeks. The primary way to protect people against the disease is vaccination, but the variability of the virus impedes development of a vaccine with long-lasting protection and makes annual changing of vaccine composition necessary (Barnett et al., 2000; Berhane et al., 2012; Mehrbod et al., 2009). De- velopment of a vaccine for a new virus strain takes time, so the key to minimizing effects of a potential pandemic may be antiviral drugs (Hedlund et al., 2010; Kwiatek et al., 2009). The available anti-flu drugs are divided into two groups: M2 ion channel inhibitors (amantadine and rimantadine) and neuraminidase inhibitors (zanamivir, oseltamivir, registered in Japan laninamivir and still tested peramivir). These substances are not free of drawbacks: they provoke side effects or their therapeutic effectiveness is undermined ( $\mathrm{Ng}$ et al., 2010). Importantly, the emergence of drug-resistant strains is frequently reported (Saito et al., 2003; Sheu et al., 2008; Nguyen et al., 2010; Ghedin et al., 2012; Ng et al., 2010).

It has been shown that seasonal H1N1 strain and H3N2 strain currently circulating in the population are mostly resistant to oseltamivir (Sheu et al., 2008; Okomo-Adhiambo et al., 2010; Hurt et al., 2009a). Among the pandemic H1N1 (2009) isolates there were also identified those having a mutation $\mathrm{H} 274 \mathrm{Y}$ in the neuraminidase gene, conditioning resistance to this drug (Payungporn et al., 2011; Okomo-Adhiambo et al., 2010; Hurt et al., 2009b; Meijer et al., 2012). Reports of oseltamivir-resistant H5N1 virus isolates (de Jong et al., 2005; Earhart et al., 2009; Triana-Baltzer et al., 2009; Hayden et al., 2005) are particularly disturbing. These facts encourage searching for new compounds of similar molecular structure, which would be active against influenza strains currently circulating in the population and the newly emerging ones (Hurt et al., 2009a; Ghedin et al., 2012). The extension of the pool of available antiviral drugs seems to be a priority in controlling influenza infections (Hayden, 2009).

\section{AIM}

The aim of this study was to evaluate the in vitro cytotoxicity and antiviral activity of eight compounds derived from oseltamivir against two strains of type A influenza

e-mail: mkolodziej@wihe.pulawy.pl

Abbreviations: DMEM, Dulbecco modified Eagle's minimal essential medium; DMF, dimethylformamide; $\mathrm{EC}_{50}$, half maximal effective concentration; FBS, fetal bovine serum; Hepes, 4-(2-hydroxyethyl)-1-piperazineethanesulfonic acid; $I_{50}$, half maximal inhibitory concentration; MIHE, Military Institute of Hygiene and Epidemiology, Warsaw, Poland; MTT, 3-(4,5-dimethylthiazol-2-yl)-2,5-diphenyltetrazolium bromide; PRI, Pharmaceutical Research Institute, Warsaw, Poland; SDS, sodium dodecyl sulfate; TCID $_{50} 50 \%$ tissue culture infective dose; TI, therapeutic index; TPCK-treated trypsin, trypsin modified by L-(tosylamido-2-phenyl) ethyl chloromethyl ketone. 
<smiles>CCC(CC)O[C@H]1C=C(C(=O)O)C[C@H](N)[C@H]1NOC</smiles>

oseltamivir carboxylate (GS4071)<smiles>[X]C(=O)C1=C[C@H](OC(CC)CC)[C@H](NOC)[C@H](N)C1</smiles>

OS-11 $\quad \mathrm{X}=\mathrm{OC}_{2} \mathrm{H}_{5}$

OS-21 $\mathrm{X}=\mathrm{OH}$

OS-27 X=NHNH<smiles>[X]C(=O)C1=C[C@H](OC(CC)CC)[C@H](N)[C@H](NC(C)=O)C1</smiles>

OS-25 X $=\mathrm{OC}_{2} \mathrm{H}_{5}$

$\begin{array}{ll}\text { OS-29 } & \mathrm{X}=\mathrm{OCH}_{3} \\ \text { OS-35 } & \mathrm{X}=\mathrm{OH}\end{array}$<smiles>CCOC(=O)C1=C[C@@H](OC(CC)CC)[C@H](NOC)[C@H](N)C1</smiles>

oseltamivir phosphate<smiles>CCC(CC)O[C@@H]1C=C(C(=O)O)C[C@H](N)[C@H]1NOC</smiles>

OS-20<smiles>CCONc1ccc(C(=O)OCC)cc1O</smiles>

OS-64<smiles>CCOC(=O)[C@@H]1C=C(OC(CC)CC)[C@H](NOC)[C@H](N(O)OC)C1</smiles>

OS-23

Figure 1. Oseltamivir and its analogs examined in this study.

virus, for selection of the original substances that would be effective and have an acceptable toxicity profile.

\section{MATERIALS AND METHODS}

Compounds. This study involved eight analogs of oseltamivir (Fig. 1), which were synthesized in the Pharmaceutical Research Institute (Warsaw). Oseltamivir carboxylate and phosphate were also obtained from PRI.

Cells. Madin-Darby Canine Kidney cells (obtained from the National Influenza Center of the National Institute of Public Health - National Institute of Hygiene, Warsaw, Poland) were cultured in DMEM (Sigma-Aldrich) supplemented with 7.5\% FBS (Sigma-Aldrich), $10 \mathrm{U} / \mathrm{ml}$ penicillin and $10 \mu \mathrm{g} / \mathrm{ml}$ streptomycin (SigmaAldrich) in culture flasks (Nunc) and 96-well plates (TPP Techno Plastic Products ) at $37^{\circ} \mathrm{C}$, under $5 \% \mathrm{CO}_{2}$. Passaging was carried out by treating cell culture with trypsin (Sigma-Aldrich) every 3 days.

Viruses. Activity of the compounds was tested against two strains of influenza virus type A: A/H1N1/PuertoRico/8/34 (kindly provided by NIPH-NIH) and A/ H3N2/HongKong/8/68 (purchased at ATCC, Manassas, VA, USA). Viruses were propagated in MDCK culture in DMEM containing antibiotics, 1\% Hepes (Sigma-Aldrich) and $2 \mu \mathrm{g} / \mathrm{ml}$ TPCK-treated trypsin (Sigma-Aldrich) at $35^{\circ} \mathrm{C}$, under $5 \% \mathrm{CO}_{2}$. After 3-4 days supernatant was collected, aliquoted and stored at $-72^{\circ} \mathrm{C}$. Titration was performed by infecting 1-day MDCK culture on a 96-well plate with 10-fold dilutions of the supernatant. After 4 days of incubation at $35^{\circ} \mathrm{C}$, under
$5 \% \mathrm{CO}_{2}$ the medium was removed from the wells and cell staining was performed using the MTT (according Levi et al., 1995, Shi et al., 2007 with modifications). 25 $\mu \mathrm{l}$ of $2.5 \mathrm{mg} / \mathrm{ml}$ solution MTT solution (Sigma-Aldrich) were added to wells. After $2 \mathrm{~h}$ incubation at $35^{\circ} \mathrm{C}, 100$ $\mu \mathrm{l}$ of lysis buffer: $13.5 \mathrm{~g} / 100 \mathrm{ml}$ SDS (POCH), $45 \%$ $(\mathrm{v} / \mathrm{v})$ DMF (Sigma-Aldrich) was added and plates were incubated overnight at $35^{\circ} \mathrm{C}$. At test termination, absorbance was measured at $\lambda=560 \mathrm{~nm}$ using Ultramark plate reader (Bio-Rad) and a TCID $_{50}$ values were determined.

Cytotoxicity of the compounds: The weighted portions of the test compounds were dissolved in DMSO (SigmaAldrich) and their 10-fold dilutions $(10 \mu \mathrm{g} / \mathrm{ml}-100 \mathrm{pg} /$ $\mathrm{ml}$ ) were prepared in DMEM with FBS, providing $0.05 \%$ concentration of DMSO in each of them. $100 \mu \mathrm{l}$ of the compound solutions were added to a 1-day MDCK culture on a 96-well plate. The culture was incubated for 4 days at $37^{\circ} \mathrm{C}$, under $5 \% \mathrm{CO}_{2}$. Then, supernatant was removed from the wells and MTT staining was performed. Each solution was examined at least in triplicate. After absorbance measurement, the concentration causing 50\% decrease in cell viability $\left(\mathrm{IC}_{50}\right)$ was determined for each compound.

Impact of the compounds on survival rate of infected cells: 1-day MDCK cultures on 96-well plates were infected with 50 $\mu \mathrm{l}$ of influenza virus at the concentration of 1000 and $100 \mathrm{TCID}_{50} / 100 \mu \mathrm{l} / 4$ days in DMEM supplemented with antibiotics, HEPES, and TPCK-treated trypsin. The solutions of the compounds $(100 \mathrm{pg} / \mathrm{ml}-10 \mu \mathrm{g} / \mathrm{ml})$, in identical medium but with addition of DMSO, were also added to wells. Plates were incubated for 4 days at 
Table 1. Cytotoxicity and antiviral activity of the compounds against $\mathrm{H} 1 \mathrm{~N} 1$ and H3N2, at infection dose of $1000 \mathrm{TCID}_{50^{\circ}}$.

\begin{tabular}{|c|c|c|c|c|c|c|c|c|c|}
\hline \multirow{3}{*}{ Compound } & \multirow{2}{*}{$\mathrm{IC}_{50}$} & \multicolumn{4}{|l|}{$\mathrm{H} 1 \mathrm{~N} 1$} & \multicolumn{4}{|l|}{$\mathrm{H} 3 \mathrm{~N} 2$} \\
\hline & & A & B & $\mathrm{EC}_{50}$ & $\mathrm{TI}$ & A & B & $\mathrm{EC}_{50}$ & $\mathrm{TI}$ \\
\hline & $(\mathrm{mg} / \mathrm{ml})$ & $(\mu \mathrm{M})$ & $(\mu \mathrm{M})$ & $(\mu \mathrm{g} / \mathrm{ml})$ & & $(\mu \mathrm{M})$ & $(\mu \mathrm{M})$ & $(\mu \mathrm{g} / \mathrm{ml})$ & \\
\hline OS-11 & 0.562 & 32.01 & 0.32 & $n / d$ & $\mathrm{n} / \mathrm{d}$ & 3.2 & 0.32 & 4 & 141 \\
\hline OS-20 & 0.501 & - & 3.22 & - & - & 3.22 & 3.22 & 7 & 72 \\
\hline OS-23 & 0.562 & - & - & - & - & - & - & - & - \\
\hline OS-25 & 0.199 & - & - & - & - & - & - & - & - \\
\hline OS-27 & 0.178 & - & 0.33 & - & - & 33.51 & 0.33 & 10 & 18 \\
\hline OS-29 & 0.178 & - & 33.5 & - & - & - & 33.5 & - & - \\
\hline OS-35 & 0.158 & 35.17 & 3.52 & $n / d$ & $n / d$ & 3.52 & 0.03 & 3 & 53 \\
\hline OS-64 & 0.063 & 44.8 & - & $\mathrm{n} / \mathrm{d}$ & $\mathrm{n} / \mathrm{d}$ & 44.8 & - & $n / d$ & $n / d$ \\
\hline OSELTAMIVIR PHOSPHATE & 0.562 & 24.37 & 2.44 & $n / d$ & $n / d$ & 2.44 & 2.44 & $n / d$ & $n / d$ \\
\hline OSELTAMIVIR CARBOXYLATE & 0.501 & $\mathrm{n} / \mathrm{t}$ & $\mathrm{n} / \mathrm{t}$ & $\mathrm{n} / \mathrm{t}$ & $\mathrm{n} / \mathrm{t}$ & $n / t$ & $n / t$ & $n / t$ & $\mathrm{n} / \mathrm{t}$ \\
\hline
\end{tabular}

MDCK cells were infected with influenza virus and treated with various drug doses. A - the lowest tested drug concentration giving a statistically significant protective effect for MDCK cells infected with a dose of $1000 \mathrm{TCID}{ }_{50} / 100 \mathrm{ml} / 4$ days in cell viability assay with $\mathrm{MTT}$ staining; B - the lowest tested drug concentration causing statistically significant reduction in hemagglutination titer of the virus; $\mathrm{n} / \mathrm{d}-\mathrm{EC}_{50}$ not determined in the range of tested doses, beyond scale; $\mathrm{n} / \mathrm{t}$ - not tested, lack of data.

$35^{\circ} \mathrm{C}$, under $5 \% \mathrm{CO}_{2}$, and then the MTT staining was performed. The assay was repeated in 3 independent experiments, each solution was examined in triplicate. After absorbance measurement, the lowest compound concentration that affect the survival rate of infected cells and concentration that helps $50 \%$ cells to survive $\left(\mathrm{EC}_{50}\right)$ were determined. The therapeutic indices (TI), i.e. $\mathrm{IC}_{50} /$ $\mathrm{EC}_{50}$ were also determined if possible.

Impact of the compounds on virus hemagglutination titer. Medium from the wells was subjected to hemagglutination test. The 2-fold solutions of medium in PBS were prepared in a 96-well plate with V-shaped bottoms and $50 \mu \mathrm{l}$ of turkey erythrocytes suspended in PBS were added. After $0.5 \mathrm{~h}$ incubation at room temperature, hemagglutination titer was evaluated visually.

Statistical analysis. The results were treated using a one-parameter analysis of variance ANOVA. Normality of data distribution was analysed with Shapiro-Wilk test, equality of variances was tested and a non-conservative post-hoc test was performed. The results were statistically significant if $p \leq 0.01$.

\section{RESULTS}

Cytotoxicity and antiviral activity are shown in Table 1 and Table 2 .

Cytotoxicity studies on MDCK cells showed that OS64, OS-35, OS-29, OS-27 and OS-25 were the most toxic compounds, whereas OS-11, OS-20 and OS-23 had the lowest toxicity that was similar to oseltamivir phosphate and carboxylate. For a higher virus dose (Table 1), antiviral activity was observed for OS-11, OS-27 and OS35. OS-64 was active only at high concentrations, OS-

Table 2. Cytotoxicity and antiviral activity of the compounds against $\mathrm{H} 1 \mathrm{~N} 1$ and $\mathrm{H} 3 \mathrm{~N} 2$ at infection dose of $100 \mathrm{TCID}_{50}$.

\begin{tabular}{|c|c|c|c|c|c|c|c|c|c|}
\hline \multirow{3}{*}{ Compound } & \multirow{2}{*}{$\mathrm{IC}_{50}$} & \multicolumn{4}{|l|}{$\mathrm{H} 1 \mathrm{~N} 1$} & \multicolumn{4}{|l|}{$\mathrm{H} 3 \mathrm{~N} 2$} \\
\hline & & $\mathrm{A}$ & $B$ & $\mathrm{EC}_{50}$ & $\mathrm{TI}$ & A & $B$ & $\mathrm{EC}_{50}$ & $\mathrm{TI}$ \\
\hline & $(\mathrm{mg} / \mathrm{ml})$ & $(\mu \mathrm{M})$ & $(\mu \mathrm{M})$ & $(\mu \mathrm{g} / \mathrm{ml})$ & & $(\mu \mathrm{M})$ & $(\mu \mathrm{M})$ & $(\mu \mathrm{g} / \mathrm{ml})$ & \\
\hline OS-11 & 0.562 & 3.3 & 0.03 & 2 & 281 & 3.3 & 0.03 & 0.6 & 937 \\
\hline OS-20 & 0.501 & 3.22 & 3.22 & 3 & 167 & 3.22 & 0.32 & 1 & 501 \\
\hline OS-23 & 0.562 & - & - & - & - & - & - & - & - \\
\hline OS -25 & 0.199 & 32 & 32 & $n / d$ & $n / d$ & - & - & - & - \\
\hline OS-27 & 0.178 & 3.35 & 0.33 & 1 & 178 & 3.35 & 0.03 & 3 & 59 \\
\hline OS-29 & 0.178 & - & 33.51 & - & - & 33.51 & 33.51 & $n / d$ & $n / d$ \\
\hline OS-35 & 0.158 & 3.52 & 0.35 & 5 & 32 & 0.35 & 0.04 & 0.06 & 2633 \\
\hline OS-64 & 0.063 & 4.48 & - & 5 & 13 & 4.48 & - & 10 & 6 \\
\hline OSELTAMIVIR PHOSPHATE & 0.562 & 2.43 & 0.24 & $n / d$ & $n / d$ & 2.43 & 0.02 & 3 & 187 \\
\hline OSELTAMIVIR CARBOXYLATE & 0.501 & 0.0004 & 0.0004 & $12 \mathrm{nM}$ & 141666 & 0.004 & 0.004 & $35 \mathrm{nM}$ & 48571 \\
\hline
\end{tabular}

MDCK cells were infected with influenza virus and treated with various drug doses. A - the lowest tested drug concentration giving a statistically significant protective effect for MDCK cells infected with a dose of $100 \mathrm{TCID} / 100 \mathrm{ml} / 4$ days in cells viability assay with $\mathrm{MTT}$ staining; B - the lowest tested drug concentration causing statistically significant reduction in hemagglutination titer of the virus; $\mathrm{n} / \mathrm{d}-\mathrm{EC}_{50}$ not determined in the range of tested doses, beyond scale. 
23 and OS-25 did not show any activity. At the dose of 1000 TCID $_{50}$ the antiviral effect was dependent on the virus strain. H3N2 strain was sensitive to ten times lower concentrations of the compounds than H1N1 strain, especially for OS-11, OS-35 and oseltamivir phosphate. At a lower infection dose (Table 2), the highest activity was observed for OS-11, OS 27, OS-35 and OS-20. OS64 showed activity only at high concentrations. OS-23 showed no activity. It has been noticed that virus strains differed partially in sensitivity to various compounds. In case of H3N2, OS-11, OS-20 and OS-35 reached values of TI higher than oseltamivir phosphate.

\section{DISCUSSION}

In studies on antiviral drugs, two main approaches can be applied. The first one is an attempt to computerized design of molecules that should have high specificity and high efficiency against influenza viruses (Rungrotmongkol et al., 2009; Hussain Basha \& Prasad, 2012; Wang et al., 2010; Durrant \& McCammon, 2010; Park \& Jo, 2010; Li et al., 2009; Mitrasinovic, 2009). However, this approach has limitations related to the difficulties in synthesizing newly designed molecules, their potential toxicity and lack of knowledge about potential metabolic transformations in the organism. Another approach is a screening test that is carried out empirically to select compounds with the strongest antiviral properties. In our case, it was a reasonable strategy because we tested derivatives of oseltamivir, which is a known antiviral drug. To assess both cytotoxicity and antiviral activity, we used MT'T staining, a method which is widely exploited in such studies (Levi et al., 1995; Shi et al., 2007). In addition, to confirm the antiviral activity in the infected cell culture, the virus titer in the culture medium was examined. It was justified by the fact that neuraminidase inhibitors are compounds able to fit in and block the active site of neuraminidase, an enzyme that is crucial for release of progeny virions from the host cell membrane. A disturbance in neuraminidase functioning may reduce the spread of the virus in a tissue and reduce the virus titer. In our studies on cytotoxicity, two compounds turned out to have a similar effect to oseltamivir phosphate, the remaining were several times more toxic. Still, when an effective antiviral demonstrates a disruptive effect on the cells, its toxicity may be reduced through chemical modifications. In our studies, the antiviral activity was noticed for three compounds, and it was evident that the infection dose and virus strains used influence the results. At a higher virus dose, antiviral activity was less manifested, and also has been affected by the virus strain. The H1N1 strain was less sensitive to the action of the compounds than the H3N2. Such a variable sensitivity among influenza virus strains was also observed by other authors (Govorkova et al., 2004; Smee et al., 2009; Smee et al., 2009). At a lower virus dose these differences disappeared. Analysis of the therapeutic index values revealed that three compounds had therapeutic activity higher than oseltmivir phosphate and two had a lower TI value. In light of these results, closer attention should be paid to the three selected derivatives of oseltamivir, OS-11, OS-27 and OS-35, which may raise hopes for the future. It must be underscored that, despite the emergence of strains resistant to known neuraminidase inhibitors, these drugs (Govorkva et al., 2001; Yamanaka et al., 2005; Vavricka et al., 2011; Kubo et al., 2010; Gubareva et al., 2001; Smee \& Sidwell, 2002), their combinations, and combinations with substances of other kinds (Govorkova et al., 2004; Nguyen et al., 2010;
Smee et al., 2009; Fukushi et al., 2012; Galabov et al., 2006; Smee et al., 2010) still have the greatest therapeutic potential. For these reasons, it seems advisable to search for compounds with similar structures that may be helpful in cases of infection with strains resistant to the currently used neuraminidase inhibitors, especially since the synthesis of oseltamivir depends on the supply of raw materials (Satoh et al., 2009; Nie \& Shi, 2009).

Our results indicate that the novel synthesized compounds used manifested their activity at a higher dose than oseltamivir carboxylate, tested by the same methods. $\mathrm{EC}_{50}$ of oseltmivir carboxylate in our study was comparable with the results of other authors (Nguyen et al., 2009; Smee et al., 2009; Smee et al., 2010). The orally administrated oseltamivir analogs may be metabolized (oseltamivir phosphate is metabolized in the liver to the active form of carboxylate (Davies, 2010)) and can exhibit antiviral activity in vivo, which justifies further research on compounds from this group. Furthermore, in contrast to known blockers of the M2 ion channel, neuraminidase inhibitors have the advantage of acting against both influenza virus type A and B (Machała \& Brydak, 2006).

\section{Acknoweldgements}

Studies were conducted under the Ministry of Science and Higher Education project No. 00001909, Activity of non-nucleosidic compounds against influenza virus strains.

\section{REFERENCES}

Barnett JM, Cadman A, Gor D, Dempsey M, Walters M, Candlin A, Tisdale M, Morley PJ, Owens IJ, Fenton RJ, Lewis AP, Claas ECJ, Rimmelzwaan GF, de Groot R, Osterhaus ADME (2000) Zanamivir susceptibility monitoring and characterization of influenza virus clinical isolates obtained during phase II clinical efficacy studies. Antimicrob Agents Chemother 44: 78-87.

Berhane Y, Kehler H, Handel K, Hisanaga T, Xu W, Ojkic D, Pasick J (2012) Molecular and antigenic characterization of reassortant H3N2 - viruses from turkeys with a unique constellation of pandemic H1N1 Internal Genes. PLOS ONE 7: e32858.

Davies BE (2010) Pharmacokinetics of oseltamivir: an oral antiviral for the treatment and prophylaxis of influenza in diverse populations. $J$ Antimicrob Chemother 65 (Suppl 2): ii5-10.

de Jong MD, Thanh TT, Truong HK, Hien VM, Smith GJD, Chau NV, Cam BV, Qui PT, Ha DQ, Guan Y, Malik Peiris JS, Hien TT, Farrar J (2005) Oseltamivir resistance during treatment of influenza A (H5N1) infection. N Engl J Med 353: 2667-2672.

Durrant JD, McCammon JA (2010) Potential drug-like inhibitors of Group 1 influenza neuraminidase identified through computer-aided drug design. Comp Biol Chem 34: 97-105.

Earhart KC, Elsayed NM, Saad MD, Gubareva LV, Nayel A, Deyde VM, Abdelsattar A, Abdelghani AS, Boynton BR, Mansour MM, Essmat HM, Klimov A, Shuck-Lee D, Monteville MR, Tjaden JA (2009) Oseltamivir resistance mutation N294S in human influenza A(H5N1) virus in Egypt. I Infect Public Health 2: 74-80.

Fukushi M, Yamashita M, Miyoshi-Akiyama T, Kubo S, Yamamoto K, Kudo K (2012) Laninamivir octanoate and artificial surfactant combination therapy significantly increases survival of mice infected with lethal influenza H1N1 virus. PLOS ONE 7: e42419.

Galabov AS, Simeonova L, Gegova G (2006) Rimantadine and oseltamivir demonstrate synergistic combination effect in an experimental infection with type A(H3N2) influenza virus in mice. Antivir Chem Chemother 17: 251-258.

Ghedin E, Holmes EC, DePasse JV, Pinilla LT, Fitch A, Hamelin ME, Papenburg J, Boivin G (2012) Presence of oseltamivir-resistant pandemic $\mathrm{A} / \mathrm{H} 1 \mathrm{~N} 1$ minor variants before drug therapy with subsequent selection and transmission. J Infect Dis 206: 1504-1511.

Govorkova EA, Fang HB, Tan M, Webster RG (2004) Neuraminidase inhibitor-rimantadine combinations exert additive and synergistic anti-influenza virus effects in MDCK Cells. Antimicrob Agents Chemother 48: 4855-4863.

Govorkova EA, Leneva IA, Goloubeva OG, Bush K, Webster RG (2001) Comparison of efficacies od RWJ-270201, Zanamivir, and Oseltamivir against H5N1, H9N2, and other avian influenza viruses. Antimicrob Agents Chemother 45: 2723-2732. 
Gubareva LV, Webster RG, Hayden FG (2001) Comparison of the Activities of Zanamivir, Oseltamivir, and RWJ-270201 against clinical isolates of influenza virus and neuraminidase inhibitor-resistant variants. Antimicrob Agents Chemother 45: 3403-3408.

Hayden F (2009) Developing new antiviral agents for influenza treatment: what does the future hold? Clin Infect Dis 48 (Suppl 1): S3S13.

Hayden F, Klimov A, Tashiro M, Hay A, Monto A, McKimm-Breschkin J, Macken C, Hampson A, Webster RG, Amyard M, Zambon M (2005) Neuraminidase Inhibitor Susceptibility Network position statement: antiviral resistance in influenza $\mathrm{A} / \mathrm{H} 5 \mathrm{~N} 1$ viruses. Antivir Ther 10: 873-877.

Hedlund M, Larson JL, Fang F (2010) Antiviral strategies for pandemic and seasonal influenza. Viruses 2: 1766-1781.

http://www.who.int/mediacentre/factsheets/avian_influenza/en/.

http://www.who.int/mediacentre/factsheets/fs211/en/.

Hurt AC, Ernest J, Deng YM, Iannello P, Besselaar TG, Birch C, Buchy P, Chittaganpitch M, Chiu SC, Dwyer D, Guigon A, Harrower B, Kei IP, Kok T, Lin C, McPhie K, Mohd A, Olveda R, Panayotou T, Rawlinson W, Scott L, Smith D, D’Souza H, Komadina N, Shaw R, Kelso A, Barr IG (2009a) Emergence and spread of oseltamivir-resistant $\mathrm{A}(\mathrm{H} 1 \mathrm{~N} 1)$ influenza viruses in Oceania, South East Asia and South Africa. Antiviral Res 83: 90-93.

Hurt AC, Holien JK, Parker MW, Barr IG (2009b) Oseltamivir resistance and the H274Y neuraminidase mutation in seasonal, pandemic and highly pathogenic influenza viruses. Drugs 69: 2523-2531.

Hussain Basha S, Prasad RN (2012) In-Silico screening of Pleconaril and its novel substituted derivatives with Neuraminidase of H1N1 Influenza strain. BMC Res Notes 5: 105.

Kubo S, Tomozawa T, Kakuta M, Tokumitsu A, Yamashita M (2010) Laninamivir Prodrug CS-8958, a Long-Acting Neuraminidase Inhibitor,Shows Superior Anti-Influenza Virus Activity after a Single Administration. Antimicrob Agents Chemother 54: 1256-1264.

Kwiatek M, Kocik J, Bartoszcze M (2009) The substances active against influenza virus. Possibilities and prospects of application. Przegl Epidemiol 63: 487-494 (in Polish).

Levi R, Beeor-Tzahar T, Arnon R (1995) Microculture virus titration - a simple colourimetric assay for influenza virus titration. J Virol Methods 52: 55-64.

Li Y, Zhou B, Wang R (2009) Rational design of Tamiflu derivatives targeting at the open conformation of neuraminidase subtype $1 . J$ Mol Graphics Modell 28: 203-219.

Machała MK, Brydak LB (2006) Various sides of influenza, part I - Structure, replication, changeability of influenza viruses, clinical course of the disease, immunological response and laboratory diagnostics. Pol Merk Lek XXI: 123, 270 (in Polish).

Mehrbod P, Motamed N, Tabatabaian M, Soleimani Estyar R, Amini E, Shahidi M, Kheiri MT (2009) In vitro antiviral of „Nanosilver” on influenza virus. DARU 17: 88-93.

Meijer A, Jonges M, van Beek P, Swaan CM, Osterhaus AD, Daniels RS, Hurt AC, Koopmans MP (2012) Oseltamivir-resistant influenza A(H1N1)pdm09 virus in Dutch travellers returning from Spain, August 2012. Euro Surveill 17: pii=20266.

Mitrasinovic PM (2009) On the structure-based design of novel inhibitors of H5N1 influenza A virus neuraminidase (NA). Biophys Chem 140: 35-38.

Ng S, Cowling BJ, Fang VJ, Chan KH, Ip DKM, Cheng CKY, Uyeki TM, Houck PM, Malik Peiris JS, Leung GM (2010) Effects of oseltamivir treatment on duration of clinical illness and viral shedding and household transmission of influenza virus. Clin Infect Dis 50: $707-714$.

Nguyen JT, Hoopes JD, Le MH, Smee DF, Patick AK, Faix DJ, Blair PJ, de Jong MD, Prichard MN, Went GT (2010) Triple combination of Amantadine, Ribavirin, and Oseltamivir is highly active and synergistic against drug resistant influenza virus strains in vitro. Antimicrob Agents Chemother 53: 4115-4126.

Nie LD, Shi XX (2009) A novel asymmetric synthesis of oseltamivir phosphate (Tamiflu) from (-)-shikimic acid. Tetrabedron: Asymmetry 20: $124-129$.

Okomo-Adhiambo M, Sleeman K, Ballenger K, Nguyen HT, Mishin VP, Sheu TG, Smagala J, Li Y, Klimov AI, Gubareva LV (2010) Neuraminidase inhibitor susceptibility testing in human influenza viruses: a laboratory surveillance perspective. Viruses 2: 2269-2289.

Park JW, Jo WH (2010) Computational design of novel, high-affinity neuraminidase inhibitors for $\mathrm{H} 5 \mathrm{~N} 1$ avian influenza virus. Eur J Med Chem 45: 536-541.

Payungporn S, Poomipak W, Makkoch J, Rianthavorn P, Theamboonlers A, Poovorawan Y (2011) Detection of oseltamivir sensitive/resistant strains of pandemic influenza A virus (H1N1) from patients admitted to hospitals in Thailand. J Virol Methods 177: 133-139.

Rungrotmongkol T, Frecer V, De-Eknamkul W, Hannongbua S, Miertus S (2009) Design of oseltamivir analogs inhibiting neuraminidase of avian influenza virus H5N1. Antiviral Res 82: 51-58.

Saito R, Sakai T, Sato I, Sano Y, Oshitani H, Sato M, Suzuki H (2003) Frequency of amantadine-resistant influenza A viruses during Two seasons featuring cocirculation of $\mathrm{H} 1 \mathrm{~N} 1$ and $\mathrm{H} 3 \mathrm{~N} 2$. I Clin Microbiol 41: 2165-2165.

Satoh N, Akiba T, Yokoshima S, Fukuyama T (2009) A practical synthesis of (-)-oseltamivir. Tetrabedron 65: 3239-3245.

Sheu TG, Deyde VM, Okomo-Adhiambo M, Gerten RJ, Xu X, Bright RA, Butler EN, Wallis TR, Klimov AI, Gubareva LV (2008) Surveillance for neuraminidase inhibitor resistance among human Influenza A and B viruses circulating worldwide from 2004-2008. Antimicrob Agents Chemother 52: 3284-3292.

Shi L, Xiong H, He J, Deng H, Li Q, Zhong Q, Hou W, Cheng L, Xiao H, Yang Z (2007) Antiviral activity of arbidol against influenza A virus, respiratory syncytial virus, rhinovirus, coxsackie virus and adenovirus in vitro and in vivo." Arch Virol 158: 1447-1455.

Smee DF, Hurst BL, Wong MH, Bailey KW, Morrey JD (2009) Effects of Double Combinations of Amantadine, Oseltamivir, and Ribavirin on influenza A (H5N1) virus infections in cell culture and in mice. Antimicrob Agents Chemother 53: 2120-2128.

Smee DF, Hurst BL, Wong MH, Bailey KW, Tarbet EB, Morrey JD, Furuta Y (2010) Effects of the combination of Favipiravir (T-705) and Oseltamivir on influenza A virus infections in mice. Antimicrob Agents Chemother 54: 126-133.

Smee DF, Sidwell RW (2002) Peramivir (BCX-1812, RWJ-27-270202): potential new therapy for influenza. Expert Opin Investig Drugs 11: 859-869.

Triana-Baltzer GB, Gubareva LV, Klimov AI, Wurtman DF, Moss RB, Hedlund M, Larson JL, Belshe RB, Fang F (2009) Inhibition of neuraminidase inhibitor-resistant influenza virus by DAS181, a novel sialidase fusion protein. PLOS ONE 4: e7838.

Vavricka CJ, Li Q, Wu Y, Qi J, Wang M, Liu Y, Gao F, Liu J, Feng E, He J, Wang J, Liu H., Jiang H, Gao GF (2011) Structural and functional analysis of laninamivir and its octanoate prodrug reveals group specific mechanisms for influenza NA inhibition. PLoS ONE 7: e1002249.

Wang SQ, Cheng XC, Dong WL, Wang RL, Chou KC (2010) Three new powerful oseltamivir derivatives for inhibiting the neuraminidase of influenza virus. Biochem Biophysi Res Commun 401: 188-191.

Yamanaka T, Tsujimura K, Kondo T, Matsumura T (2006) In vitro efficacies of Oseltamivir carboxylate and Zanamivir against equine influenza A viruses. J Vet Med Sci 68: 405-408. 